This item was submitted to Loughborough's Research Repository by the author.

Items in Figshare are protected by copyright, with all rights reserved, unless otherwise indicated.

\title{
Systemic financial crises and the housing market cycle
}

PLEASE CITE THE PUBLISHED VERSION

http://dx.doi.org/10.1080/13504851.2017.1361001

PUBLISHER

(c) Taylor \& Francis

VERSION

AM (Accepted Manuscript)

PUBLISHER STATEMENT

This work is made available according to the conditions of the Creative Commons Attribution-NonCommercialNoDerivatives 4.0 International (CC BY-NC-ND 4.0) licence. Full details of this licence are available at: https://creativecommons.org/licenses/by-nc-nd/4.0/

\section{LICENCE}

CC BY-NC-ND 4.0

\section{REPOSITORY RECORD}

Agnello, Luca, Vitor Castro, and Ricardo M. Sousa. 2019. "Systemic Financial Crises and the Housing Market Cycle". figshare. https://hdl.handle.net/2134/26123. 


\title{
Systemic Financial Crises and \\ the Housing Market Cycle*
}

\author{
Luca Agnello ${ }^{\dagger}$ \\ Vitor Castro $\ddagger$ \\ University of Palermo \\ Loughborough University and NIPE \\ Ricardo M. Sousa ${ }^{\S}$ \\ University of Minho, NIPE and London School of Economics
}

\begin{abstract}
Using quarterly data for a group of 20 industrialized countries and both continuous- and discrete-time duration models, we show that financial crisis recessions are associated with a two- to three-fold increase in the likelihood of the end of a housing boom. Additionally, recessions preceded by booms in mortgage credit are especially damaging, as their occurrence coincides with an increase in the duration of housing market slumps of almost $90 \%$.
\end{abstract}

Keywords: housing booms and busts, duration analysis, financial crises.

JEL Classification: C41, E32, E51, E52.

\footnotetext{
${ }^{*}$ Castro and Sousa acknowledge that this work has been financed by Operational Programme for Competitiveness Factors COMPETE and by National Funds through the FCT - Portuguese Foundation for Science and Technology within the remit of the project "FCOMP-01-0124-FEDER-037268 (PEst-C/EGE/UI3182/2013)".

${ }^{\dagger}$ University of Palermo, Department of Economics, Business and Statistics (SEAS), Viale delle Scienze, 90128 Palermo, Italy. Email: luca.agnello01@unipa.it.

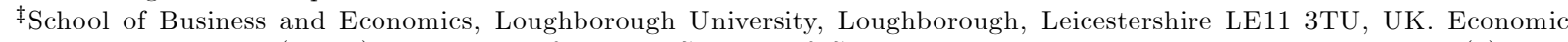
Policies Research Unit (NIPE), University of Minho, Campus of Gualtar, 4710-057 Braga, Portugal. Phone: +44(0) 1509 222706; E-mail: v.m.q.castro@lboro.ac.uk

$\S$ University of Minho, Department of Economics and Economic Policies Research Unit (NIPE), Campus of Gualtar, 4710-057 - Braga, Portugal; London School of Economics and Political Science, LSE Alumni Association, Houghton Street, London WC2 2AE, United Kingdom. Emails: rjsousa@eeg.uminho.pt, rjsousa@alumni.lse.ac.uk.
} 


\section{Introduction}

Due to the skyrocketing of household debt to asset ratios, credit booms have become a source of financial stability risks (Jordà et al., 2016). On the one hand, the growth of banks' balance sheet and the upward trend in the share of the income of the financial sector in total income have given housing finance a prominent role in the modern macroeconomy (Schularick and Taylor, 2012; Jordà et al., 2013). On the other hand, excessive exposure to risk and slow economic recoveries are just the other "faces" of "too big too fail" financial institutions and the consequences of debt overhang (Reinhart and Rogoff, 2009; Agnello and Sousa, 2012; Agnello et al., 2015a).

Bracke (2013) shows that likelihood of the end of housing downturns is lower when previous upturns have been unusually long. Bénétrix et al. (2012) use a probit model and also find that the probability of a house price slump ending is higher when the pre-slump house price upturn is smaller. In addition, Bénétrix et al. (2012) and Bracke (2013) highlight the importance of some macroeconomic variables in shaping housing cycles. Bénétrix et al. (2012) also emphasise that housing slumps are shorter when housing supply is more rigid and financial institutions are more developed.

We move one step forward vis-à-vis the work of Agnello et al. (2015b) in that we use not only the continuous-time Weibull model, but also different discrete-time duration models, which contemplate the incorporation of time-variant explanatory variables. Additionally, we improve vis-a-vis the study by Agnello et al. (forthcoming) in that we explicitly condition the duration of the various phases of the housing market cycle on the occurrence of different typologies of recession episodes.

We find that financial crisis recessions are associated with shorter housing booms and their effects are more detrimental for the duration of these spells than normal recessions. Moreover, longer housing busts somewhat accrue to the occurrence of systemic financial crises. Consequently, recessions preceded by booms in mortgage credit are more prone to coincide with protracted slumps in the housing market.

\section{Econometric framework}

To implement discrete-time methods, we can start with a continuous-time duration model and, then, derive the appropriate estimator for data grouped into intervals. Let us define the discrete-time hazard rate as $P_{i t}=\operatorname{Pr}\left[T_{i}=t \mid T_{i}>t, x_{i t}\right]$, where $T_{i}$ is the discrete random variable representing the uncensored time at which the event ends and $x_{i t}$ is a vector of time-varying explanatory variables. Prentice and Gloeckler (1978) show that the discrete-time proportional hazard function can be expressed as

$$
P_{i t}=1-\exp \left[-h_{t} \exp \left(\boldsymbol{\beta}^{\prime} \mathbf{x}_{i t}\right)\right]=1-\exp \left[-\exp \left(\theta_{t}+\boldsymbol{\beta}^{\prime} \mathbf{x}_{i t}\right)\right]
$$

which is equivalent to the so called complementary log-log (or cloglog) function $\ln \left[-\ln \left(1-P_{i t}\right)\right]=\theta_{t}+\beta^{\prime} x_{i t}$, where $\theta_{t}\left(=\ln h_{t}\right)$ represents the logarithm of an unspecified (baseline hazard) function of time, $x_{i t}$ is a vector of time-varying explanatory variables and the vector of coefficients $\beta$ is a $(K \times 1)$ vector of parameters to be estimated.

To estimate the discrete-time analogue to the Weibull model the model, $\theta_{t}$ represents , i.e. $\theta_{t}=\ln h_{t}=$ 
$\alpha+(p-1) \ln t$, where $h_{t}$ represents the hazard function, which measures the rate at which housing booms, busts or normal times will end at $t$, given that they lasted until that moment. The discrete-time log-likelihood function for a sample of $i=1, \ldots, n$ spells can be written as

$$
\ln L(\cdot)=\sum_{i=1}^{n} \sum_{j=1}^{t_{i}} y_{i t} \ln \left(\frac{P_{i j}}{1-P_{i j}}\right)+\sum_{i=1}^{n} \sum_{j=1}^{t_{i}} \ln \left(1-P_{i j}\right)
$$

where the dummy variable $y_{i t}$ is equal to 1 if the housing boom, bust or normal time $i$ ends at time $t$, and

0 otherwise. Plugging equation (1) into equation (2) and using the adequate specification for the baseline hazard function, one can estimate the model by Maximum Likelihood.

\section{Data}

Our analysis covers a sample of 20 industrialized countries over the period 1970Q1-2012Q2. ${ }^{1}$ The main data used in our study consists of spells which measure the duration (in quarters) of housing booms, busts or normal times (Dur). Such episodes are identified using the quarterly series of real housing price indices as provided by the Organisation for Economic Co-Operation and Development (OECD). Basically, we identify housing booms and busts as major and persistent deviations from long-term trends. The identification procedure consists of the following steps. First, we smooth quarterly house price growth using a five-quarter moving average. This avoids capturing high-frequency changes. Second, we run a preliminary detection of upturns and downturns in real housing prices by looking at periods of consecutive positive and negative growth in real housing prices. Finally, the price change in an upturn (downturn) is required to exceed (fall below) a minimum (maximum) threshold before it can be labelled as a boom (bust). This threshold is set to $15 \%$, which is close to the average size of upturns and downturns over the entire sample period and assumes that these episodes are symmetric. ${ }^{2}$ Normal times in the housing market cycle cover all non-boom and non-bust episodes, which implies that this phase includes both upturns and downturns in real housing prices that are not identified as booms and busts.

In order to investigate the role played by crisis episodes on the duration of the different phases of the housing market cycle, we add dummy variables (one at time) to the set of regressors. These control for the occurrence of 1) systemic financial crises (SystemicCrises), 2) normal recessions (NormalCrises), and 3) financial crisis recessions (FinancialCrises), as described in Jordà et al. (2016). Due to the lack of data, these crisis episodes are coded as missing for Greece, Ireland, Korea and New Zealand.

As additional explanatory variables, we consider: $(i)$ the real GDP growth rate $(R G D P),(i i)$ the lending interest rate $(L R) ;($ iii $)$ the growth rate of domestic credit to the private sector $(C R)$. These determinants of the housing market cycle are obtained from the International Financial Statistics of the International Monetary Fund (IMF).

Finally, we construct a dummy variable (European) that takes the value of one in European countries

\footnotetext{
${ }^{1}$ Appendix A provides the list of countries included in the analysis.

${ }^{2}$ We have also considered different thresholds for housing booms and housing busts. For instance, the threshold has been set equal to the average size of housing upturns and housing downturns over the entire sample of analysis (i.e. $23 \%$ and $-11 \%$, respectively). The results remained qualitatively and quantitatively unchanged and are available upon request.
} 
and zero otherwise, which allows us to test the existence of significant differences in the length of housing booms/busts in European countries vis-à-vis non-European countries.

\section{Empirical results}

The empirical findings are reported in Tables 1 (housing booms), 2 (housing busts) and 3 (normal times). Columns 1-2 report the findings associated with the estimation of a continuous-time Weibull model, while Columns 3-4 show the summary of the results of the discrete-time Cloglog model that is analogue to the continuous-time Weibull model. In Columns 5-6, the Cloglog regressions are performed using natural cubic splines of the hazard functions.

In Table 1, we find that systemic financial crises (SystemicCrises) are normally associated with shorter housing booms, even though the effect is significant only at the $10 \%$ level. However, both normal recessions (NormalCrises) and financial crisis recessions (FinancialCrises) are strongly significant across the various duration models under consideration. Their coefficients are positive, thereby, implying that the occurrence of these types of recessions has a large and significant impact on the length of housing booms: this phase of the housing market cycle is considerably shortened when such crisis episodes emerge. Interestingly, the Cloglog regressions that are performed using natural cubic splines of the hazard functions reveal that the coefficient associated with financial crisis recessions is larger in magnitude than in the case of normal recessions. This result is consistent with the work of Jordà et al. (2016), which shows that the former episodes have a more damaging effect on the macroeconomy than the latter episodes. Indeed, the authors argue that financial crisis recessions tend to be followed by slower economic recoveries.

Table 2 presents the results for housing busts. As the dummy variables for normal recessions (NormalCrises) and financial crisis recessions (FinancialCrises) are omitted, we are not able to assess their impact. Despite this, the empirical findings suggest that the occurrence of systemic financial crises tends to make housing busts longer: the coefficient associated with SystemicCrises is negative and significant in the case of the continuous-time (Weibull) duration model. Thus, periods of strong rise in real estate lending typically lead to deeper recessionary episodes. Yet, no significant effect is observed in the discrete-time duration models.

Table 3 reports the findings for normal times. In this case, the dummy variable for systemic financial crisis recessions (SystemicCrises) is omitted, but we can investigate the effects of normal recessions (NormalCrises) and financial crisis recessions (FinancialCrises). The results show that, although normal recessions do not impact the duration of normal times in the housing market in a significant manner, financial crisis recessions lead to a large and significant reduction of their length: the coefficient associated with FinancialCrises is positive and large in magnitude, thus, implying that the occurrence of financial crisis recessions unequivocally increases the likelihood of the end of normal times in the housing market.

To assess the economic significance of these results, note that the impact of a change of any given explanatory variable, $x_{i t}$, on the hazard rate is computed, approximately, as $e^{x_{i t}}$. As the coefficient associated with SystemicCrises ranges between 1.205 and 1.373 (in the case of housing booms) and is equal to -2.274 (in the case of housing busts), this implies that (i) the occurrence of systemic financial crises leads to a twoto three-fold increase in the likelihood of the end of a housing boom; and (ii) the same episodes prolong the 
duration of housing busts by almost $90 \%$.

Finally, with regard to the various macroeconomic variables included as regressors, the empirical evidence uncovers four main findings. First, an acceleration of real GDP growth prolongs (shortens) housing booms (busts) or promotes the transition from normal times to housing booms. Consequently, a strong economic performance, as well as growth-enhancing policies, can boost the recovery from a prolonged period of downturn in real housing prices, but also serve as a catalyst for a sharp appreciation of real housing prices. Second, a tightening of money market conditions reduces the length of housing booms. Therefore, central bank actions - for instance, interest rate hikes - can be particularly effective at mitigating periods of housing price over-valuation and eliminating large deviations of housing prices from their fundamental values. Third, a rise in the growth rate of credit to the domestic sector does not significantly impact the housing market cycle. Thus, as in Agnello et al. (forthcoming), the impact of credit on the housing market cycle (and the length of its various phases) mainly operates via changes in its cost than via changes in its availability. Fourth, housing busts and normal time spells are typically shorter in European countries than in non-European countries. This result confirms the evidence provided by Agnello et al. (2015b, forthcoming).

[ INSERT TABLE 1 HERE. ]

[ INSERT TABLE 2 HERE. ]

[ INSERT TABLE 3 HERE. ]

\section{Conclusions}

Using quarterly data for 20 industrialized countries and various duration models, we investigate the impact of recession episodes on the dynamics of the housing market cycle. In particular, we condition the duration of housing booms, housing busts and normal times in the housing markets on the occurrence of recessions, and distinguish between systemic crisis episodes and normal versus financial crisis recessions.

We find that both financial crisis recessions and normal recessions considerably shorten the duration of housing booms, but the former episodes tend to have a more damaging effect than the latter. The length of normal times in the housing market cycle is also significantly reduced when financial crisis recessions occur.

Additionally, systemic financial crises make housing busts somewhat longer. Therefore, recessions that are preceded by booms in mortgage credit have a particularly detrimental impact on the dynamics of the housing market cycle.

From a policy perspective, our work suggests that macro-prudential policies can be an important shield of the economy vis-a-vis the deleterious effect of housing busts and the financial stability risks associated with housing booms. Moreover, given the impact of monetary policy on the length of the various phases of the housing market cycle, a policy framework encompassing a mix of monetary and macro-prudential policies can prove particularly effective at preventing and/or dampening boom-bust cycles.

While providing valuable information on the timing and the length of the different phases of the housing market cycle, this article opens new avenues for further research. A promising direction consists on rigorously assessing the role played by housing finance regulation in shortening the duration of boom-bust episodes. In 
addition, in light of the importance of financialisation in the housing sector, a thorough understanding of the housing market cycle requires the ability to account for the impact of securitisation and the degree of liberalisation of the mortgage market. We leave this work for the future.

\section{References}

[1] Agnello, L., Castro, V., Jalles, J., Sousa, R.M., 2015a. Do debt crises boost financial reforms? Applied Economics Letters, 22(5), 356-360.

[2] Agnello, L., Castro, V., Sousa, R.M., 2015b. Booms, busts and normal times in the housing market. Journal of Business and Economic Statistics, 33(1), 25-45.

[3] Agnello, L., Castro, V., Sousa, R.M., forthcoming. Economic activity, credit market conditions and the housing market. Macroeconomic Dynamics. doi:10.1017/S1365100516000869.

[4] Agnello, L., Sousa, R.M., 2015. How do banking crises impact on income inequality? Applied Economics Letters, 19, 1425-1429.

[5] Bénétrix, A.S., Eichengreen, B., O'Rourke, K.H., 2012. How housing slumps end. Economic Policy, 27, 649-692.

[6] Bracke, P., 2013. How long do housing cycles last? A duration analysis from 19 OECD countries. Journal of Housing Economics, 22, 213-230.

[7] Burnside, C., Eichenbaum, M., Rebelo, S., 2016. Understanding booms and busts in housing markets. Journal of Political Economy, 124(4), 1088-1147.

[8] Jordà, O., Schularick, M., Taylor, A.M., 2013. When credit bites back. Journal of Money, Credit and Banking, 45(S2), 3-28.

[9] Jordà, O., Schularik, M., Taylor, A.M., 2016. The Great Mortgaging: Housing finance, crises, and business cycles. Economic Policy, 31(85), 107-152

[10] Prentice, R., Gloeckler, L., 1978. Regression analysis of grouped survival data with application to the breast cancer data. Biometrics, 34, 57-67.

[11] Reinhart, C.M., Rogoff, K.S., 2009. This time is different: Eight centuries of financial folly. Princeton, N.J.: Princeton University Press.

[12] Schularick, M., Taylor, A.M., 2012. Credit booms gone bust: Monetary policy, leverage cycles, and financial crises, 1870-2008. American Economic Review, 102(2), 1029-1061. 


\section{Appendix}

\section{A List of Tables}

Table 1: Continuous-time (Weibull) and discrete-time (Cloglog) estimations for housing booms.

\begin{tabular}{|c|c|c|c|c|c|c|c|}
\hline & $(1)$ & $(2)$ & $(3)$ & $(4)$ & & $(5)$ & $(6)$ \\
\hline \multirow[t]{3}{*}{$p$} & $\begin{array}{c}2.036^{+, c} \\
(0.211)\end{array}$ & $\begin{array}{c}2.243^{+, c} \\
(0.204)\end{array}$ & $\begin{array}{c}1.917^{+, c} \\
(0.373)\end{array}$ & $\begin{array}{c}2.254^{+, c} \\
(0.381)\end{array}$ & Spline1 & $\begin{array}{c}0.180^{* * *} \\
(0.043)\end{array}$ & $\begin{array}{c}0.213^{* * *} \\
(0.041)\end{array}$ \\
\hline & & & & & Spline2 & $\begin{array}{c}-0.230^{* *} \\
(0.110)\end{array}$ & $\begin{array}{c}-0.279^{* *} \\
(0.121)\end{array}$ \\
\hline & & & & & Spline3 & $\begin{array}{l}1.020^{*} \\
(0.584)\end{array}$ & $\begin{array}{l}1.242^{*} \\
(0.661)\end{array}$ \\
\hline$R G D P$ & & & $\begin{array}{c}-0.189^{* * *} \\
(0.046)\end{array}$ & $\begin{array}{c}-0.202^{* * *} \\
(0.045)\end{array}$ & $R G D P$ & $\begin{array}{c}-0.185^{* * *} \\
(0.046)\end{array}$ & $\begin{array}{c}-0.198^{* * *} \\
(0.044)\end{array}$ \\
\hline$C R$ & & & $\begin{array}{c}0.008 \\
(0.013)\end{array}$ & $\begin{array}{l}-0.019 \\
(0.026)\end{array}$ & $C R$ & $\begin{array}{c}0.006 \\
(0.013)\end{array}$ & $\begin{array}{l}-0.019 \\
(0.025)\end{array}$ \\
\hline$L R$ & & & $\begin{array}{c}0.333^{* * *} \\
(0.076)\end{array}$ & $\begin{array}{c}0.338^{* * *} \\
(0.066)\end{array}$ & $L R$ & $\begin{array}{c}0.330^{* * *} \\
(0.079)\end{array}$ & $\begin{array}{c}0.331^{* * *} \\
(0.070)\end{array}$ \\
\hline European & $\begin{array}{c}0.333 \\
(0.372)\end{array}$ & $\begin{array}{c}0.139 \\
(0.355)\end{array}$ & $\begin{array}{l}-0.432 \\
(0.352)\end{array}$ & $\begin{array}{l}-0.059 \\
(0.335)\end{array}$ & European & $\begin{array}{l}-0.446 \\
(0.352)\end{array}$ & $\begin{array}{l}-0.070 \\
(0.336)\end{array}$ \\
\hline SystemicCrises & $\begin{array}{l}1.205^{* *} \\
(0.512)\end{array}$ & & $\begin{array}{l}1.271^{*} \\
(0.730)\end{array}$ & & SystemicCrises & $\begin{array}{l}1.373^{*} \\
(0.741)\end{array}$ & \\
\hline NormalCrises & & $\begin{array}{c}1.960^{* * *} \\
(0.353)\end{array}$ & & $\begin{array}{c}1.786^{* * *} \\
(0.562)\end{array}$ & NormalCrises & & $\begin{array}{c}1.876^{* * *} \\
(0.517)\end{array}$ \\
\hline FinancialCrises & & $\begin{array}{c}1.770^{* * *} \\
(0.435)\end{array}$ & & $\begin{array}{c}3.078^{* * *} \\
(0.716)\end{array}$ & FinancialCrises & & $\begin{array}{c}3.171^{* * *} \\
(0.671)\end{array}$ \\
\hline Constant & $\begin{array}{c}-6.838^{* * *} \\
(0.813)\end{array}$ & $\begin{array}{c}-7.936^{* * *} \\
(0.823)\end{array}$ & $\begin{array}{c}-11.337^{* * *} \\
(1.697)\end{array}$ & $\begin{array}{c}-12.826^{* * *} \\
(1.650)\end{array}$ & Constant & $\begin{array}{c}-8.797^{* * *} \\
(1.152)\end{array}$ & $\begin{array}{c}-9.804^{* * *} \\
(0.946)\end{array}$ \\
\hline $\log L$ & $\begin{array}{l}-39.99 \\
\end{array}$ & -35.28 & -137.0 & -127.7 & $\log L$ & -138.3 & -128.6 \\
\hline$A I C$ & 87.98 & 80.57 & 288.08 & 271.30 & $A I C$ & 294.67 & 277.27 \\
\hline$S B I C$ & 95.47 & 89.93 & 322.88 & 311.08 & $S B I C$ & 339.42 & 326.98 \\
\hline$L R I$ & - & - & 0.226 & 0.279 & $L R I$ & 0.219 & 0.273 \\
\hline Observ. & 48 & 48 & 1066 & 1066 & Observ. & 1066 & 1066 \\
\hline Ended & - & - & 42 & 42 & Ended & 42 & 42 \\
\hline
\end{tabular}

Notes: Robust standard errors (clustered by country) for the estimated coefficients are in parentheses. Significance level at which the null hypothesis is rejected: ${ }^{* *}, 1 \% ;{ }^{* *}, 5 \%$; and ${ }^{*}, 10 \%$. The sign "+" indicates that $p$ is significantly higher than 1 using a $5 \%$ one-sided test with robust standard errors; $d, c$ and $i$, indicate the presence of decreasing, constant or increasing positive duration dependence at a $5 \%$ level, respectively. $A I C=2[-\log L+k]$ and $S B I C=2[-\log L+(k / 2) \log N]$, where $\log L$ is the log-likelihood for the estimated model, $k$ is the number of regressors and $N$ is the number of observations. $L R I$ is the likelihood ratio index or pseudo- $R^{2}\left(L R I=1-\log L / \log L_{0}\right.$, where $L_{0}$ is the likelihood of the model without regressors). "Ended" indicates de number of non-zero observations in the Cloglog model, which also corresponds to the number of housing booms. The economic variables are lagged one period in order to avoid simultaneity problems and to account for the usual delays in the reporting of economic data. Columns (1)-(2) present the results of a continuous-time Weibull model. Columns (3)-(4) show the results of a discrete-time Cloglog model that is analogue to the continuous-time Weibull model. In Columns (5)-(6), the Cloglog regressions are performed using natural cubic splines of the hazard functions, with knots at periods 1,30 , 45 and 68 . 
Table 2: Continuous-time (Weibull) and discrete-time (Cloglog) estimations for housing busts.

\begin{tabular}{|c|c|c|c|c|c|c|c|}
\hline & $(1)$ & 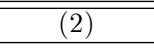 & $\overline{(3)}$ & $(4)$ & & $(5)$ & 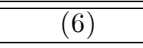 \\
\hline \multirow[t]{3}{*}{$p$} & $\begin{array}{c}2.503^{+, c} \\
(0.523)\end{array}$ & $\begin{array}{c}2.023^{+, c} \\
(0.310)\end{array}$ & $\begin{array}{c}2.085^{+, c} \\
(0.328)\end{array}$ & $\begin{array}{c}1.986^{+, c} \\
(0.335)\end{array}$ & Spline1 & $\begin{array}{c}0.240^{* * *} \\
(0.059)\end{array}$ & $\begin{array}{c}0.230^{* * *} \\
(0.067)\end{array}$ \\
\hline & & & & & Spline2 & $\begin{array}{c}-0.769^{* * *} \\
(0.226)\end{array}$ & $\begin{array}{c}-0.741^{* * *} \\
(0.255)\end{array}$ \\
\hline & & & & & Spline3 & $\begin{array}{c}2.970^{* * *} \\
(0.977)\end{array}$ & $\begin{array}{c}2.830^{* * *} \\
(1.057)\end{array}$ \\
\hline$R G D P$ & & & $0.467^{* * *}$ & $0.482^{* * *}$ & $R G D P$ & $0.507^{* * *}$ & $0.506^{* * *}$ \\
\hline & & & $(0.165)$ & $(0.178)$ & & $(0.186)$ & $(0.194)$ \\
\hline$C R$ & & & $\begin{array}{l}-0.027 \\
(0.085)\end{array}$ & $\begin{array}{r}-0.020 \\
(0.081)\end{array}$ & $C R$ & $\begin{array}{l}-0.024 \\
(0.085)\end{array}$ & $\begin{array}{l}-0.019 \\
(0.081)\end{array}$ \\
\hline$L R$ & & & $\begin{array}{c}0.048 \\
(0.044)\end{array}$ & $\begin{array}{c}0.041 \\
(0.043)\end{array}$ & $L R$ & $\begin{array}{c}0.046 \\
(0.049)\end{array}$ & $\begin{array}{c}0.038 \\
(0.049)\end{array}$ \\
\hline European & $\begin{array}{l}2.725^{* *} \\
(1.087)\end{array}$ & $\begin{array}{l}1.937^{* *} \\
(0.861)\end{array}$ & $\begin{array}{c}1.479 \\
(1.066)\end{array}$ & $\begin{array}{l}1.440 \\
(1.033)\end{array}$ & European & $\begin{array}{c}0.807 \\
(0.923)\end{array}$ & $\begin{array}{c}0.649 \\
(0.851)\end{array}$ \\
\hline SystemicCrises & $\begin{array}{c}-2.274^{* * *} \\
(0.569)\end{array}$ & & $\begin{array}{c}0.052 \\
(0.882)\end{array}$ & & SystemicCrises & $\begin{array}{c}0.729 \\
(1.294)\end{array}$ & \\
\hline NormalCrises & & Omitted & & Omitted & NormalCrises & & Omitted \\
\hline FinancialCrises & & Omitted & & Omitted & FinancialCrises & & Omitted \\
\hline Constant & $\begin{array}{c}-10.479^{* * *} \\
(2.487)\end{array}$ & $\begin{array}{c}-8.404^{* * *} \\
(1.581)\end{array}$ & $\begin{array}{c}-8.158^{* * *} \\
(1.518)\end{array}$ & $\begin{array}{c}-7.714^{* * *} \\
(1.538)\end{array}$ & Constant & $\begin{array}{c}-7.809^{* * *} \\
(1.426)\end{array}$ & $\begin{array}{c}-7.316^{* * *} \\
(1.300)\end{array}$ \\
\hline $\log L$ & -18.57 & -22.42 & -80.94 & -79.38 & $\log L$ & -77.09 & -75.52 \\
\hline$A I C$ & 43.14 & 50.84 & 175.89 & - & $A I C$ & 172.18 & - \\
\hline$S B I C$ & 47.02 & 54.73 & 206.30 & - & $S B I C$ & 211.27 & - \\
\hline$L R I$ & - & - & 0.131 & - & $L R I$ & 0.172 & - \\
\hline Observ. & 27 & 27 & 569 & 508 & Observ. & 569 & 508 \\
\hline Ended & - & - & 22 & 22 & Ended & 22 & 22 \\
\hline
\end{tabular}

Notes: Robust standard errors (clustered by country) for the estimated coefficients are in parentheses. Significance level at which the null hypothesis is rejected: ${ }^{* *}, 1 \% ;{ }^{* *}, 5 \%$; and ${ }^{*}, 10 \%$. The sign " + " indicates that $p$ is significantly higher than 1 using a $5 \%$ one-sided test with robust standard errors; $d, c$ and $i$, indicate the presence of decreasing, constant or increasing positive duration dependence at a $5 \%$ level, respectively. $A I C=2[-\log L+k]$ and $S B I C=2[-\log L+(k / 2) \log N]$, where $\log L$ is the $\log$-likelihood for the estimated model, $k$ is the number of regressors and $N$ is the number of observations. $L R I$ is the likelihood ratio index or pseudo- $R^{2}\left(L R I=1-\log L / \log L_{0}\right.$, where $L_{0}$ is the likelihood of the model without regressors). "Ended" indicates de number of non-zero observations in the Cloglog model, which also corresponds to the number of housing busts. The economic variables are lagged one period in order to avoid simultaneity problems and to account for the usual delays in the reporting of economic data. Columns (1)-(2) present the results of a continuous-time Weibull model. Columns (3)-(4) show the results of a discrete-time Cloglog model that is analogue to the continuous-time Weibull model. In Columns (5)-(6), the Cloglog regressions are performed using natural cubic splines of the hazard functions, with knots at periods $1,30,45$ and 85. 
Table 3: Continuous-time (Weibull) and discrete-time (Cloglog) estimations for normal times.

\begin{tabular}{|c|c|c|c|c|c|c|c|}
\hline & $(1)$ & $\overline{(2)}$ & 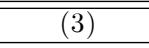 & $(4)$ & & $(5)$ & $(6)$ \\
\hline \multirow[t]{3}{*}{$p$} & $\begin{array}{c}1.386^{+, d} \\
(0.169)\end{array}$ & $\begin{array}{c}1.442^{+, d} \\
(0.155)\end{array}$ & $\begin{array}{c}1.192 \\
(0.195)\end{array}$ & $\begin{array}{l}1.280 \\
(0.176)\end{array}$ & Spline 1 & $\begin{array}{c}0.013 \\
(0.038)\end{array}$ & $\begin{array}{c}0.023 \\
(0.036)\end{array}$ \\
\hline & & & & & Spline 2 & $\begin{array}{l}-0.049 \\
(0.193)\end{array}$ & $\begin{array}{l}-0.081 \\
(0.188)\end{array}$ \\
\hline & & & & & Spline3 & $\begin{array}{c}0.246 \\
(0.730)\end{array}$ & $\begin{array}{c}0.342 \\
(0.719)\end{array}$ \\
\hline$R G D P$ & & & $0.197^{* *}$ & $0.199^{* *}$ & $R G D P$ & $0.200^{* *}$ & $0.200^{* *}$ \\
\hline & & & $(0.093)$ & $(0.086)$ & & $(0.091)$ & $(0.087)$ \\
\hline$C R$ & & & 0.027 & 0.025 & $C R$ & 0.027 & 0.026 \\
\hline & & & $(0.017)$ & $(0.017)$ & & $(0.017)$ & $(0.017)$ \\
\hline$L R$ & & & $\begin{array}{c}0.032 \\
(0.033)\end{array}$ & $\begin{array}{c}0.028 \\
(0.038)\end{array}$ & $L R$ & $\begin{array}{c}0.038 \\
(0.035)\end{array}$ & 0.034 \\
\hline European & $\begin{array}{c}1.391^{* * *} \\
(0.475)\end{array}$ & $\begin{array}{c}1.417^{* * *} \\
(0.462)\end{array}$ & $\begin{array}{c}1.346^{* * *} \\
(0.414)\end{array}$ & $\begin{array}{c}1.386^{* * *} \\
(0.424)\end{array}$ & European & $\begin{array}{c}1.425^{* * *} \\
(0.454)\end{array}$ & $\begin{array}{c}1.425^{* * *} \\
(0.445)\end{array}$ \\
\hline SystemicCrises & Omitted & & Omitted & & SystemicCrises & Omitted & \\
\hline NormalCrises & & $\begin{array}{c}0.351 \\
(0.289)\end{array}$ & & $\begin{array}{l}-0.955 \\
(1.023)\end{array}$ & NormalCrises & & $\begin{array}{l}-0.925 \\
(1.011)\end{array}$ \\
\hline FinancialCrises & & $\begin{array}{c}2.335^{* * *} \\
(0.361)\end{array}$ & & $\begin{array}{c}1.656^{* * *} \\
(0.468)\end{array}$ & FinancialCrises & & $\begin{array}{c}1.355^{* * *} \\
(0.457)\end{array}$ \\
\hline Constant & $\begin{array}{c}-5.499^{* * *} \\
(0.781)\end{array}$ & $\begin{array}{c}-5.751^{* * *} \\
(0.717)\end{array}$ & $\begin{array}{c}-5.047^{* * *} \\
(0.778)\end{array}$ & $\begin{array}{c}-5.250^{* * *} \\
(0.778)\end{array}$ & Constant & $\begin{array}{c}-4.904^{* * *} \\
(0.725)\end{array}$ & $\begin{array}{c}-4.979^{* * *} \\
(0.742)\end{array}$ \\
\hline $\log L$ & -56.35 & -54.85 & -122.9 & -122.2 & $\log L$ & -122.6 & -122.2 \\
\hline$A I C$ & 118.70 & 117.71 & - & 260.31 & $A I C$ & - & 264.38 \\
\hline$S B I C$ & 124.32 & 125.19 & - & 297.17 & $S B I C$ & - & 310.46 \\
\hline$L R I$ & - & - & - & 0.074 & $L R I$ & - & 0.074 \\
\hline Observ. & 48 & 48 & 721 & 741 & Observ. & 721 & 741 \\
\hline Ended & - & - & 32 & 32 & Ended & 32 & 32 \\
\hline
\end{tabular}

Notes: Robust standard errors (clustered by country) for the estimated coefficients are in parentheses. Significance level at which the null hypothesis is rejected: ${ }^{* *}, 1 \% ;{ }^{* *}, 5 \%$; and ${ }^{*}, 10 \%$. The sign "+" indicates that $p$ is significantly higher than 1 using a $5 \%$ one-sided test with robust standard errors; $d, c$ and $i$, indicate the presence of decreasing, constant or increasing positive duration dependence at a $5 \%$ level, respectively. $A I C=2[-\log L+k]$ and $S B I C=2[-\log L+(k / 2) \log N]$, where $\log L$ is the $\log$-likelihood for the estimated model, $k$ is the number of regressors and $N$ is the number of observations. $L R I$ is the likelihood ratio index or pseudo- $R^{2}\left(L R I=1-\log L / \log L_{0}\right.$, where $L_{0}$ is the likelihood of the model without regressors). "Ended" indicates de number of non-zero observations in the Cloglog model, which also corresponds to the number of normal time spells. The economic variables are lagged one period in order to avoid simultaneity problems and to account for the usual delays in the reporting of economic data. Columns (1)-(2) present the results of a continuous-time Weibull model. Columns (3)-(4) show the results of a discrete-time Cloglog model that is analogue to the continuous-time Weibull model. In Columns (5)-(6), the Cloglog regressions are performed using natural cubic splines of the hazard functions, with knots at periods 1,35 , 60 and 107. 
Appendix

A Appendix

Table 4: List of countries included in the sample.

\begin{tabular}{cccc}
\hline \hline Australia & France & Japan & Spain \\
Belgium & Germany & Korea & Sweden \\
Canada & Greece & Netherlands & Switzerland \\
Denmark & Ireland & New Zealand & United Kingdom \\
Finland & Italy & Norway & United States \\
\hline \hline
\end{tabular}

